Check for updates

Cite this: RSC Adv., 2017, 7, 41889

\title{
Pyrolysis gas as a carbon source for biogas production via anaerobic digestion
}

\author{
Yeqing Li, ${ }^{a}$ Dongfang Su, ${ }^{a}$ Sen Luo, ${ }^{a}$ Hao Jiang, ${ }^{a}$ Mingyu Qian, ${ }^{\text {ab }}$ Hongjun Zhou, ${ }^{a}$ \\ Jason Street, ${ }^{c}$ Yan Luo ${ }^{d}$ and Quan Xu (D)*a
}

\begin{abstract}
Carbon is an important resource for anaerobes to enhance biogas production. In this study, the possibility of using simulated pyrolysis gas (SPG) as a carbon source for biogas production was investigated. The effects of stirring speed (SS), gas holding time (GHT), and $\mathrm{H}_{2}$ addition on biomethanation of SPG were evaluated. The diversity and structure of microbial communities were also analyzed under an illumina MiSeq platform. Results indicated that at a GHT of $14 \mathrm{~h}$ and an SS at $400 \mathrm{rpm}$, SPG with up to $64.7 \% \mathrm{CH}_{4}$ could be bio-upgraded to biogas. Gas-liquid mass transfer is the limitation for SPG biomethanation. For the first time, it has been noticed that the addition of $\mathrm{H}_{2}$ can bioupgrade SPG to high quality biogas (with 91.1\% $\mathrm{CH}_{4}$ ). Methanobacterium was considered as a key factor in all reactors. This study provides an idea and alternative way to convert lignocellulosic biomass and solid organic waste into energy (e.g., pyrolysis was used as a pretreatment to produce pyrolysis gas from biomass, and then, pyrolysis gas was bioupgraded to higher quality biogas via anaerobic digestion).
\end{abstract}

Received 3rd August 2017 Accepted 17th August 2017

DOI: 10.1039/c7ra08559a

rsc.li/rsc-advances and carbon dioxide $\left(\mathrm{CO}_{2}\right)$, and minor components are other gases, e.g., methane $\left(\mathrm{CH}_{4}\right)$ and some volatile impurities) from biomass (e.g., lignocellulosic biomass, industrial and municipal solid waste, lignite, and digestate).$^{8-11}$ One advantage of this process is that most of the organic components, especially the relatively dry and slowly biodegradable biomass (e.g., wood and woodchips) that are not suitable or effective for anaerobic digestion $(\mathrm{AD})$ process, would be converted to pyrolysis gas. However, CO is a toxic gas for many organisms due to its high affinity for metal-containing enzymes. The presence of high concentrations of $\mathrm{CO}$ is a restriction in the utilization of pyrolysis gas in some applications. ${ }^{7,11}$ Moreover, low volumetric energy density (usually less than $13 \mathrm{MJ} \mathrm{m}^{-3}$ ) is a limitation for pyrolysis gas when used as a fuel gas. ${ }^{\mathbf{8}, 12}$ To convert the pyrolysis gas into high quality gas, a methanation process is necessary. Traditional catalytic methanation requires high pressure and temperature $\left(230-700{ }^{\circ} \mathrm{C}\right)$ and a metal catalyst, which involves high cost and energy consumption. A potentially more economical alternative is the utilization of a biological system to convert biomass pyrolysis gases to biomethane. Several trials have been reported to biologically convert $\mathrm{CO}, \mathrm{H}_{2}$, and $\mathrm{CO}_{2}$ to biomethane via biomethanation system. ${ }^{13}$ Wang et al. ${ }^{14}$ reported that co-digestion of coke oven gas (COG) $\left(92 \% \mathrm{H}_{2}\right.$ and $8 \% \mathrm{CO}$ ) and sewage sludge could achieve in situ biogas upgradation and simultaneous COG biomethanation. Youngsukkasem et $a .^{15}$ found that using syngas and organic substances as feedstock for $\mathrm{AD}$ in a repeated batch mode, a good performance without any negative effect was observed. The conversion of $\mathrm{H}_{2}$ and $\mathrm{CO}_{2}$ to $\mathrm{CH}_{4}$ is a common biological reaction occurring in the anaerobic digestion reactor. Only
${ }^{a}$ State Key Laboratory of Heavy Oil Processing, Beijing Key Laboratory of Biogas Upgrading Utilization, Institute of New Energy, China University of Petroleum Beijing (CUPB), Beijing, 102249, P. R. China.E-mail: xuquan@cup.edu.cn

${ }^{b}$ Faculty of Agricultural and Environmental Sciences, University of Rostock, Justus-vonLiebig-Weg 6, 18059 Rostock, Germany

${ }^{c}$ Department of Sustainable Bioproducts, Mississippi State University, Mississippi State, 39762, USA

${ }^{d}$ Department of Chemical Engineering, West Virginia University, USA 
a small number of microorganisms (e.g., Methanobacterium thermoautotrophicum, Methanosarcina barkeri, Methanothermobacter thermautotrophicus, and Methanosaeta thermophila) can achieve CO biomethanation. ${ }^{\mathbf{1 3 , 1 6 , 1 7}}$ Since the solubility of $\mathrm{H}_{2}$ is $0.00016 \mathrm{~g}$ per $100 \mathrm{~g}$ of water above $1 \mathrm{~atm}$ and the solubility of $\mathrm{CO}$ is $0.0028 \mathrm{~g}$ per $100 \mathrm{~g}$ of water above $1 \mathrm{~atm}$, anaerobic digestion of pyrolysis gas is typically limited by the gas-liquid mass transfer rate. ${ }^{13}$ From the view of thermodynamics, the reaction $\mathrm{CO}+\mathrm{H}_{2} \rightarrow \mathrm{CH}_{4}$ is exothermic. However, in the biomethanation reaction, no significant temperature changes were found due to the low conversion rate of biocatalysis as compared to traditional catalytic methanation. Actually, in the anaerobic digestion process, the system needs to be maintained at a constant temperature of $37^{\circ} \mathrm{C}$ to keep the microorganisms at a higher biocatalytic activity. The constant temperature is provided by an extra heat source. Thus, development of a suitable reactor and optimization of operating conditions are necessary. Moreover, a low cost and long-term $\mathrm{AD}$ operation is needed to industrialize the pyrolysis gas biomethanation technology.

Based on the abovementioned considerations, in this study, biomethanation was achieved in long-term AD tests where SPG was utilized as a carbon source for biogas production. AD can increase the LVC of SPG from 12.9 to $23.2 \mathrm{MJ} \mathrm{m}^{-3}$, and Methanobacterium was dominant in the whole process. The conversion rates of $\mathrm{CO}$ and $\mathrm{H}_{2}$ were $96.6 \%$ and $99.2 \%$, respectively, which could effectively enhance gas production. The objectives of this study were as follows: (1) to investigate the effect of stirring intensity (SS), gas holding time (GHT), and $\mathrm{H}_{2}$ addition on biomethanation of pyrolysis gas and (2) to evaluate the system stability using pyrolysis gas as a carbon source in longterm anaerobic digestion operation.

\section{Experimental}

\subsection{Experiment setup}

Herein, three $1.69 \mathrm{~L}$ continuously stirred tank reactors (named R1-R3) with a working volume of $1.2 \mathrm{~L}$ were used. Non acclimated inoculum was obtained from the mixed effluent of anaerobic reactors treating various organic wastes (e.g., chicken manure, dairy manure, corn stover and food waste) in our laboratory. Before utilization, the residual solid matter in effluent was removed using a sieve. Then, liquid inoculum was pre-incubated at a constant temperature $\left(37^{\circ} \mathrm{C}\right)$ incubator shaker (ZWYR-D2402, China) for degassing. The shaking speed was $120 \mathrm{rpm}$. After two weeks of pre-incubation, no gas was detected from inoculum. Then, the degassed inoculum was transferred to three reactors. The total solids (TS) and volatile solids (VS) of inoculum were $2.33 \pm 0.02 \% \mathrm{FM}$ and $1.03 \pm 0.00 \%$ FM, respectively. To ensure an oxygen-free environment, the headspace of each reactor was purged with nitrogen gas for 2 min. The digestion temperature was $37^{\circ} \mathrm{C}$. Simulated pyrolysis gas $\left(\mathrm{H}_{2}: \mathrm{CO}: \mathrm{CH}_{4}: \mathrm{CO}_{2}=35: 30: 15: 20\right.$ on volume basis) was manually added to the reactors by a $100 \mathrm{~mL}$ syringe. Once added, pyrolysis gas was kept in the reactors for $24 \mathrm{~h}$ or $48 \mathrm{~h}$ depending on the experiment design (Table 1 ). To bioupgrade the generated gas from the reactor R2, pure hydrogen and generated gas from R2 were added to the reactor R3. To investigate the process stability of using simulated pyrolysis gas as the only substrate, no additional carbon source was added to this system. During steady-states, the liquid samples were obtained from R1-R3 for high-throughput 16S rRNA sequencing and analysis. Specific experiment design is shown in Table 1.

\subsection{Cross-linking process}

TS and VS were determined according to the standard methods. ${ }^{18}$ Gas samples were obtained every one or two days to detect the composition. A gas chromatograph (FULI 9790II, China) equipped with a thermal conductivity detector (TCD) was used with helium as the carrier gas. The temperatures of the injector, oven, and detector were 150,130 , and $160{ }^{\circ} \mathrm{C}$, respectively. The corrected $\mathrm{CH}_{4}, \mathrm{CO}, \mathrm{CO}_{2}$, and $\mathrm{H}_{2}$ content of the produced gas (i.e. $\mathrm{CH}_{4 \text { corr }}, \mathrm{CO}_{\text {corr }}, \mathrm{CO}_{4 \text { corr }}$, and $\mathrm{H}_{2 \text { corr }}$ ) was calculated according to $\mathrm{Li}$ et al. ${ }^{19}$ Biogas production of all reactors was measured daily by a $100 \mathrm{~mL}$ syringe. The $\mathrm{pH}$ was measured using a pH meter (SARTORIUS PB-10). The volatile fatty acids (VFA) and total inorganic carbon (TIC) were measured using a Mettler Toledo T70. Then, $7 \mathrm{~mL}$ sample was taken using a pipette $(3.5 \mathrm{~mL}$ twice) into the titration beaker, and water was added to $40 \mathrm{~mL}$ scale line; then, the titration beaker was put on the titrator, the titration was started to adjust the $\mathrm{pH}$ of the sample to 5.0, 4.4, 4.3, and 4.0 with $0.025 \mathrm{~mol} \mathrm{~L}^{-1}$ $\mathrm{H}_{2} \mathrm{SO}_{4}$, and the volume of $\mathrm{H}_{2} \mathrm{SO}_{4}$ used for each $\mathrm{pH}$ value was

Table 1 Summary of the experiment design and performance in the reactors R1, R2, and R3 during steady states

\begin{tabular}{|c|c|c|c|c|c|c|}
\hline & $\begin{array}{l}\text { Phase } 1 \\
\text { (1-43 days) }\end{array}$ & $\begin{array}{l}\text { Phase } 2 \\
\text { (44-59 days) }\end{array}$ & $\begin{array}{l}\text { Phase } 3 \\
(60-91 \text { days })^{a}\end{array}$ & $\begin{array}{l}\text { Reactor R2 } \\
\text { Phase } 1 \\
\text { (1-86 days) }\end{array}$ & $\begin{array}{l}\text { Phase } 1 \\
\text { (1-21 days) }\end{array}$ & $\begin{array}{l}\text { Phase } 2 \\
\text { (22-63 days) }\end{array}$ \\
\hline Gas flow rate $\left(\mathrm{mL} \mathrm{d}^{-1}\right)$ & $163 \pm 7$ & $325 \pm 7$ & $505 \pm 11$ & $325 \pm 7$ & $270 \pm 39^{c}$ & $363 \pm 33^{c}$ \\
\hline Initial CO partial pressure (atm) & 0.20 & 0.20 & 0.21 & 0.20 & NA & NA \\
\hline Initial $\mathrm{H}_{2}$ partial pressure (atm) & 0.23 & 0.23 & 0.62 & 0.23 & NA & NA \\
\hline Stirring speed (rpm) & 120 & 120 & 120 & 400 & 400 & 400 \\
\hline
\end{tabular}

${ }^{a}$ Gas composition $\left(\mathrm{H}_{2}: \mathrm{CO}: \mathrm{CH}_{4}: \mathrm{CO}_{2}=4.5: 1.5: 0.75: 1\right.$, on volume basis). ${ }^{b}$ Day $11-13$, the gas holding time was adjusted to $24 \mathrm{~h}$.

${ }^{c}$ Calculations were obtained based on 10 measurements during steady states. 
obtained. The VFA and VFA/TIC were then calculated according to Nie et al. ${ }^{20}$

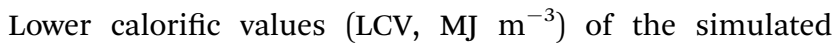
pyrolysis gas and generated gas were determined according to Li et $a .^{8}$

During steady-states, the liquid samples were obtained in phase 1 and 2 of the reactor R1 (named R1P1 and R1P2), phase 1 of the reactor R2 (named R2P1), and phase 1 of the reactor R3 (named R3P1) for sequencing using an Illumina MiSeq platform at Majorbio Company (Shanghai, China). Inoculum was also analyzed as a control. Microbial DNA was extracted from samples using the E.Z.N.A.®AxyPrepDNA Kit (Omega Bio-tek, Norcross, GA, U.S.) according to manufacturer's protocols. The V4-V5 region of the bacteria 16S ribosomal RNA gene was amplified by PCR $\left(95^{\circ} \mathrm{C}\right.$ for $2 \mathrm{~min}$, followed by 25 cycles at $95{ }^{\circ} \mathrm{C}$ for $30 \mathrm{~s}, 55^{\circ} \mathrm{C}$ for $30 \mathrm{~s}$, and $72{ }^{\circ} \mathrm{C}$ for $30 \mathrm{~s}$ and a final extension at $72{ }^{\circ} \mathrm{C}$ for $5 \mathrm{~min}$ ) using primers Arch519F and Arch915R. PCR reactions were performed in triplicate $20 \mu \mathrm{L}$ mixture containing $4 \mu \mathrm{L}$ of $5 \times$ FastPfu Buffer, $2 \mu \mathrm{L}$ of $2.5 \mathrm{mM}$ dNTPs, $0.8 \mu \mathrm{L}$ of each primer $(5 \mu \mathrm{M}), 0.4 \mu \mathrm{L}$ of FastPfu Polymerase, and $10 \mathrm{ng}$ of template DNA.

Operational taxonomic units (OTUs) were clustered with 97\% similarity cut-off using UPARSE (version 7.1 http:// drive5.com/uparse/), and chimeric sequences were identified and removed using UCHIME. The taxonomy of each 16S rRNA gene sequence was analysed by RDP Classifier (http:// rdp.cme.msu.edu/) against the silva (SSU115) 16S rRNA database using the confidence threshold of $70 \%$. Specific Illumina MiSeq sequencing procedures and processing of sequencing data can be found.

\section{Results and discussion}

\subsection{Effect of the gas holding time (GHT)}

The time course of biogas production, biogas composition, $\mathrm{pH}$, VFA concentrations, and VFA/TIC ratio are shown in Fig. 1-3. Table 1 summarizes the reactor performance during steadystates of each operation condition. Reactor R1 was operated at a low stirring speed (SS) of $120 \mathrm{rpm}$. Biogas production increased from $60 \pm 5 \mathrm{~mL} \mathrm{~d}^{-1}$ to $114 \pm 24 \mathrm{~mL} \mathrm{~d}^{-1}$ with the gas holding time (GHT) decreasing from $48 \mathrm{~h}$ to $24 \mathrm{~h}$. The corresponding $\mathrm{CH}_{4}$ content was decreased from $62.2 \pm 1.3 \%$ to $49.9 \pm 1.3 \%$. The $\mathrm{CO}$ and $\mathrm{H}_{2}$ conversion efficiency were $93.3 \pm$ $1.2 \%$ and $98.5 \pm 0.5 \%$ in phase 1 and $91.5 \pm 2.3 \%$ and $85.1 \pm$ $3.9 \%$ in phase 2 , respectively. Change in the GHT can influence the $\mathrm{CH}_{4}$ content, and $\mathrm{CO}$ and $\mathrm{H}_{2}$ conversion efficiency; this indicates that the contact time of gas and liquid is an important parameter for SPG biomethanation. For reactor R1, on increasing the injected gas flow from $325 \mathrm{~mL} \mathrm{~d}^{-1}$ to $505 \mathrm{~mL} \mathrm{~d}^{-1}$ (325 $\mathrm{mL} \mathrm{SPG}+180 \mathrm{~mL} \mathrm{H}_{2}$ ), the biogas production increased. However, high percentages of $\mathrm{H}_{2}$ and $\mathrm{CO}$ were also determined in generated biogas (phase 3), indicating that the biomethanation efficiency in this operation was low. The corresponding $\mathrm{H}_{2}$ and $\mathrm{CO}$ conversion efficiency were only $84.0 \pm$ $3.6 \%$ and $77.5 \pm 2.4 \%$, respectively. The methane content in phase 3 of R1 was also low as compared to that in phase 1 of R1.

\subsection{Effect of the stirring speed (SS)}

For the reactor $\mathrm{R} 2, \mathrm{H}_{2}$ and $\mathrm{CO}$ were not detected in the generated gas at SS of $400 \mathrm{rpm}$ and GHT of $24 \mathrm{~h}$; this indicated that they were efficiently utilized by the microorganisms in the reactor. Methane content was $64.7 \pm 0.8 \%$ in R2 when the SS was adjusted to $400 \mathrm{rpm}$ (Table 1 and Fig. 2), indicating that SS was a higher influence factor on biomethanation of SPG as compared to GHT. Similar results were found by Luo and Angelidaki ${ }^{21}$ indicating that increase in the stirring speed of the reactor from 150 to $300 \mathrm{rpm}$ could increase $\mathrm{H}_{2}$ consumption rate. As reported by Guiot et al. ${ }^{13}$ gaseous feedstock is difficult to be captured by the microbes in the liquid phase. Further study should be focussed on the conversion efficiency of pyrolysis gas biomethanation and minimization of the gasliquid mass transfer limitation. From 60 to 72 days, reactor R2 was only maintained at $37{ }^{\circ} \mathrm{C}$ without the input of SPG and
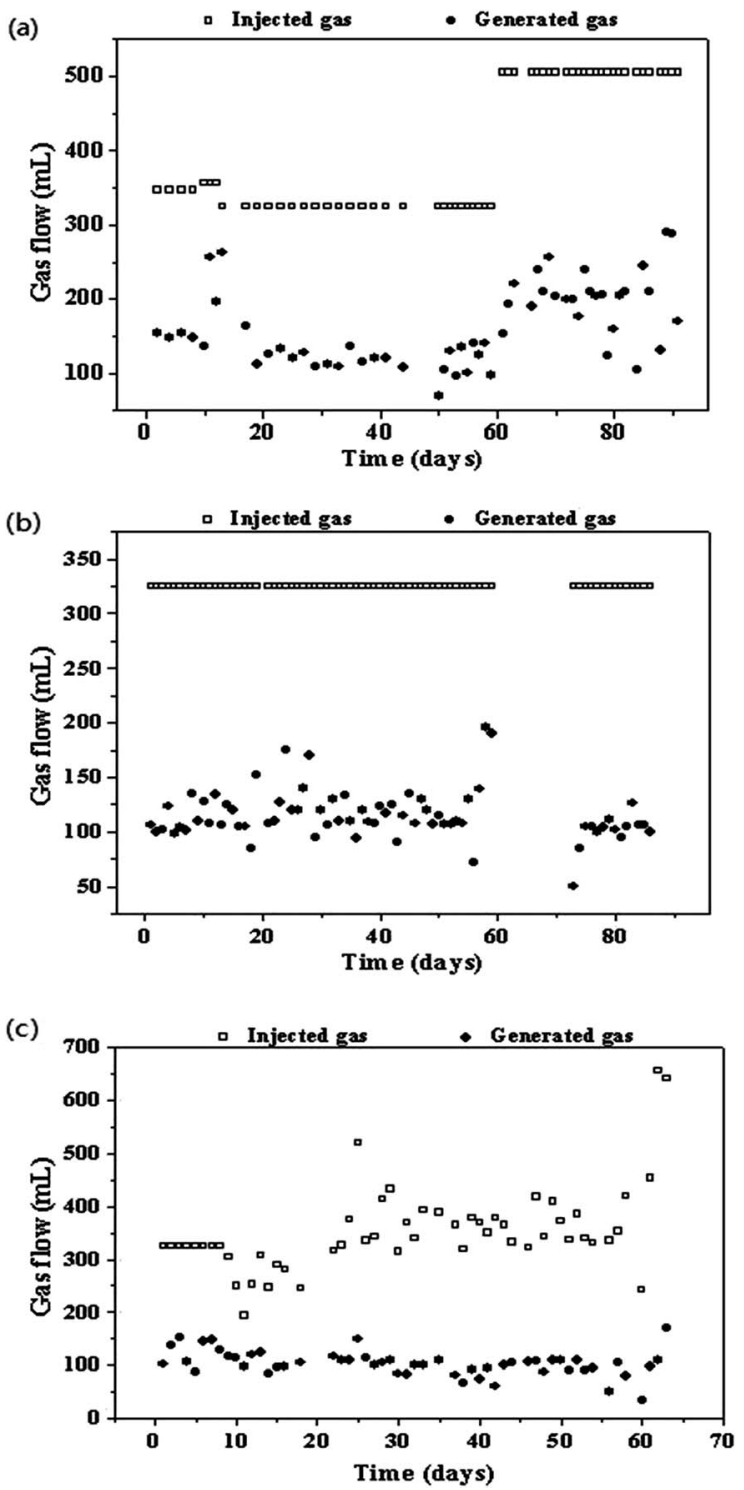

Fig. 1 Profiles of the gas injection and generation rate $(a, b$, and $c$ representing the reactor $\mathrm{R} 1, \mathrm{R} 2$, and $\mathrm{R} 3$, respectively). 

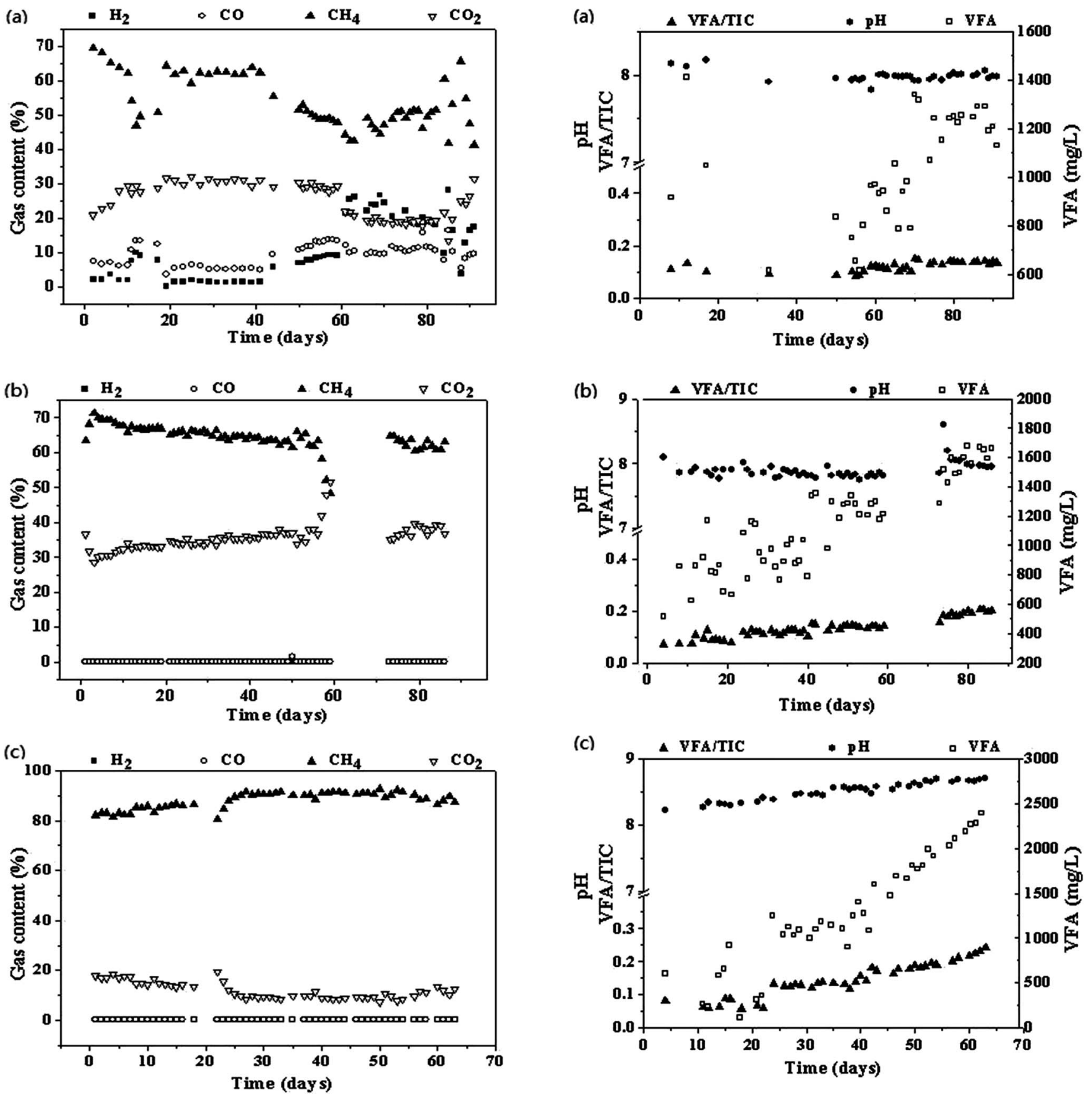

Fig. 2 Profiles of biogas composition ( $a, b$, and $c$ representing the reactor R1, R2, and R3, respectively).

output of generated gas due to the absence of researcher. On 73rd day, this reactor was recovered with feeding SPG, and it performed well in the next days.

\subsection{Effect of hydrogen addition}

In reactor $\mathrm{R} 3$, injected gas was composed by generated gas from reactor $\mathrm{R} 2\left(\mathrm{CH}_{4}\right.$ content was $\left.64.7 \pm 0.8 \%\right)$ and additional $\mathrm{H}_{2}$. The addition of $\mathrm{H}_{2}$ reached $116 \pm 11 \mathrm{~mL}$ and $241 \pm 33 \mathrm{~mL}$ per day in phase 1 and phase 2 of R3, respectively (Table 1). The corresponding $\mathrm{CH}_{4}$ contents were $85.7 \pm 1.0 \%$ and $91.1 \pm 1.0 \%$, respectively, which indicated that addition of $\mathrm{H}_{2}$ could largely increase the $\mathrm{CH}_{4}$ content (Fig. 2). Luo and Angelidaki ${ }^{22}$ found that the addition of $\mathrm{H}_{2}$ could achieve in situ biogas upgradation (methane content was from $78.4 \%$ to $90.2 \%$ ) when using mixture of cattle manure and whey as feedstock. In this study, SPG was used as a carbon source. Moreover, through the addition of $\mathrm{H}_{2}$, SPG biomethanation was achieved. $\mathrm{H}_{2}$ can be generated from electrolysis of water using extra electricity or unstable wind electricity, or water photolysis or methanol decomposition. The $\mathrm{H}_{2}$-assisted bioupgradation has several advantages, such as no $\mathrm{CH}_{4}$ loss, low investment cost for 
Table 2 Reaction equations of $\mathrm{CO} /$ synthesis gas biocatalysis

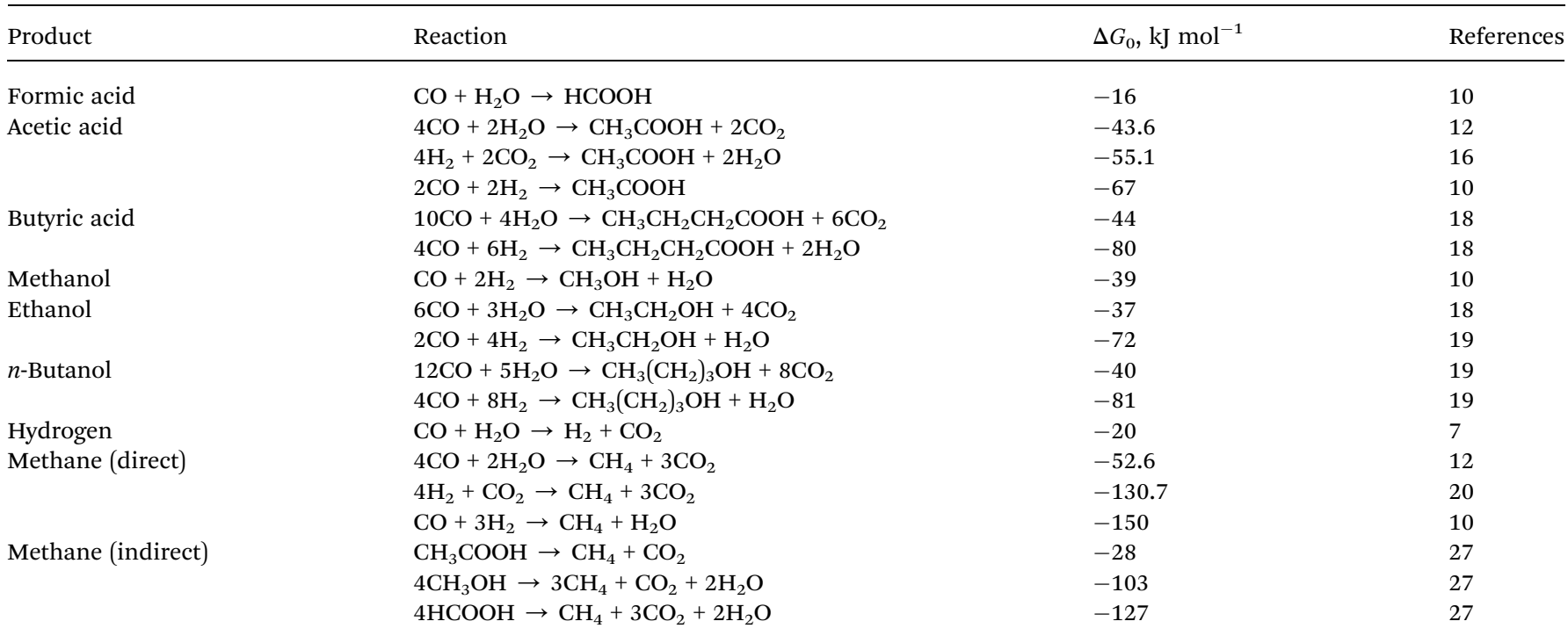

additional equipment, and storage of excess electricity as methane, as compared to $\mathrm{CO}_{2}$-air strippers or autogenerative high pressure digestion (AHPD) method.

\subsection{Calculation of mass balance}

Due to the SPG containing $15 \%$ of $\mathrm{CH}_{4}$ as a feed gas in the experiments, the mass balance discussion is necessity. Taking R1P1 for example, the SPG addition is $163 \mathrm{~mL}$ with $15 \% \mathrm{CH}_{4}$ (24.5 $\mathrm{mL} \mathrm{CH}_{4}$ added), and the biogas production is $60 \mathrm{~mL}$ with 62.2\% $\mathrm{CH}_{4}$ (37.3 $\mathrm{mL} \mathrm{CH} \mathrm{CH}_{4}$ produced); thus, the pure $\mathrm{CH}_{4}$ production is $12.8 \mathrm{~mL}$. Similar calculation results for all the other phases are shown in Table 1 . The results further inferred that $\mathrm{CO}, \mathrm{CO}_{2}$, and $\mathrm{H}_{2}$ were converted to methane by the anaerobic microbes.

\subsection{Evaluation of the energy output}

Although pyrolysis gas can be directly used as fuel gas, the volumetric energy density of pyrolysis gas is only about $50 \%$ of biogas. The conversion of pyrolysis gas to $\mathrm{CH}_{4}$ is an important step to meet the increasing demand for natural gas. After SPG biomethanation, the energy output results are shown in Table 1. According to the lower calorific value (LCV) calculation equation, ${ }^{8}$ the lower calorific value of injected gas $\left(\mathrm{LCV}_{\mathrm{in}}\right)$ for R1 and R2 was determined to be $12.2-12.9 \mathrm{MJ} \mathrm{m}^{-3}$. After biomethanation process, the lower calorific value of generated gas $\left(\mathrm{LCV}_{\text {out }}\right)$ ranged from 20.4 to $23.2 \mathrm{MJ} \mathrm{m}{ }^{-3}$. For reactor $\mathrm{R} 3, \mathrm{LCV}_{\text {out }}$ was $30.7-32.7 \mathrm{MJ} \mathrm{m}^{-3}$ after the addition of $\mathrm{H}_{2}$. Herein, two-step approach (SPG biomethanation and $\mathrm{H}_{2}$ addition) could be a minder and alternative way to bioupgrade pyrolysis gas into high quality biogas and convert toxic gas $\mathrm{CO}$ to $\mathrm{CH}_{4}$.

\subsection{Process stability}

During the long-term anaerobic digestion tests, using SPG as a carbon source, $\mathrm{pH}$ value was around 8.0 for R1 and R2 and
8.3-8.6 for $\mathrm{R} 3$. The $\mathrm{pH}$ value increased to higher than 8.0 in reactor R3 (Table 1 and Fig. 3) as $\mathrm{H}_{2}$ addition was associated with the consumption of $\mathrm{CO}_{2}$ in the reactors. Similar result was obtained by Luo and Angelidaki, ${ }^{22,23}$ where manure alone was used as a substrate and $\mathrm{pH}$ value in reactor increased to higher than 8.0. In this study, no significant inhibition was found although the $\mathrm{pH}$ value was not in the optimum range of 7.2-7.8. The VFA concentration showed an increasing trend with time and was determined to be $770-1058 \mathrm{mg} \mathrm{L}^{-1}$ for R1, $913 \mathrm{mg} \mathrm{L}^{-1}$ for R2, and 463-1727 $\mathrm{mg} \mathrm{L}^{-1}$ for R3. The VFA/TIC ratios of R1$\mathrm{R} 3$ were lower than 0.4 , which were in a normal range. ${ }^{19}$ Generally, anaerobic reactors can perform well using SPG as a carbon source when the $\mathrm{pH}$ in the reactors remains above 8.0.

\subsection{Microbial community analysis}

Reaction equations of $\mathrm{CO} /$ synthesis gas biocatalysis are summarized in Table 2. $\mathrm{CO}$ and $\mathrm{H}_{2}$ from synthesis gas can be converted to $\mathrm{CH}_{4}$ in two ways: direct and indirect conversions. In the first reaction, $\mathrm{CH}_{4}$ was formed directly via conversion of $\mathrm{CO}, \mathrm{H}_{2}$, and $\mathrm{CO}_{2}$ by microorganisms. ${ }^{22}$ In the second reaction,

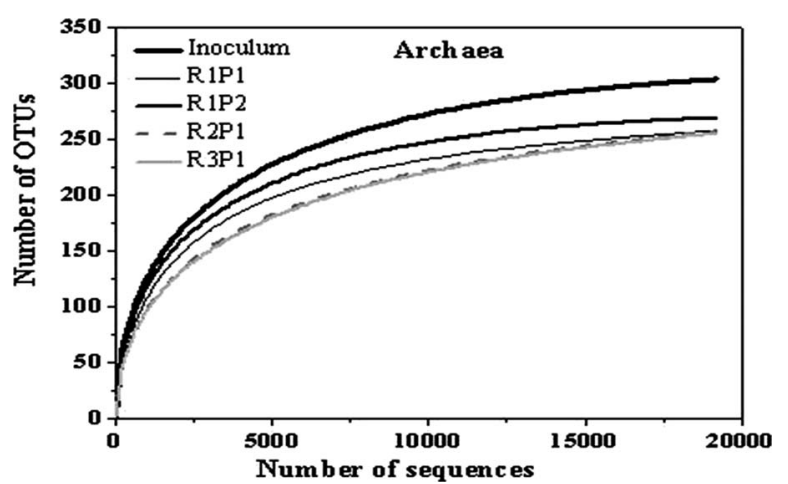

Fig. 4 Rarefaction curves based on the sequencing of archaea communities. The OTUs were defined by the 0.03 distance. 


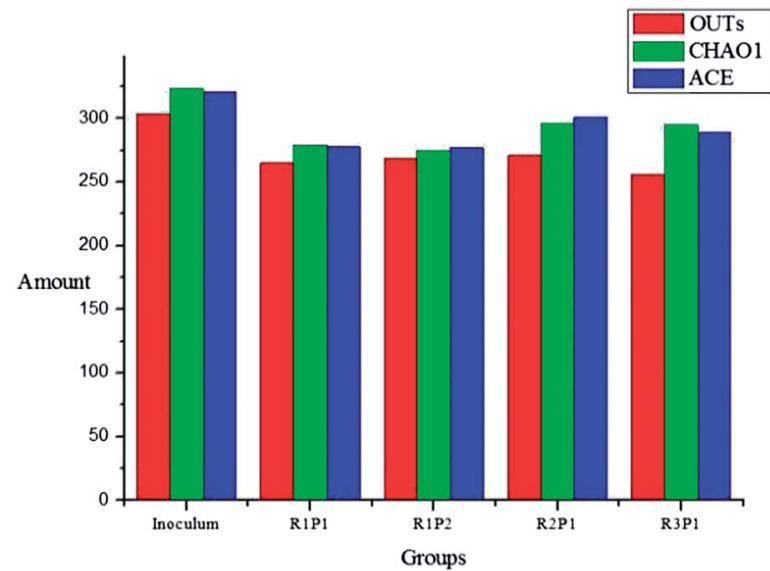

Fig. 5 Comparison of the richness and diversity of the 16S RNA gene libraries based on the 0.03 distance.

intermediate products (e.g., formic acid, methanol, and acetic acid) were formed, and then, $\mathrm{CH}_{4}$ was observed by degradation of the intermediate products. ${ }^{24-26}$

Fig. 4 shows the rarefaction curves based on an operational taxonomic units (OTU) definition of 97\% sequence similarity. New OTUs continue to appear even after sampling 2000 sequences for archaea. However, the coverage values for archaea $(>99 \%)$ indicated that most common OTUs were detected (Fig. 5). The Shannon diversity, CHAO1, and ACE richness index provides not only species richness but also the evenness of the species among all the species in the community. In the current work, inoculum had higher diversity and richness as compared to other samples. This may be because inoculum was obtained from the mixed effluent of anaerobic digesters treating various organic wastes, and samples from reactors R1-R3 were only fed with SPG.

At the phyla level, Euryarchaeota $(>97 \%)$ was dominant in all these samples. The genus level identification of the archaea communities is illustrated in Fig. 6. Methanobacterium dominated in all samples. The amounts of other archaea communities are different in 5 groups; this is in accordance with the

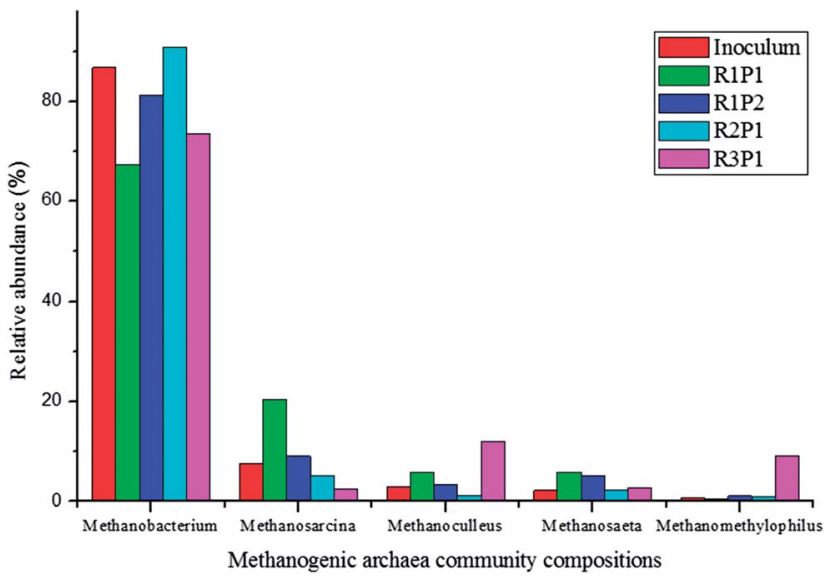

Fig. 6 Methanogenic archaea community compositions. report of Luo and Angelidaki. ${ }^{21}$ Furthermore, we assigned the sequences to species level by choosing representative sequences from each dominant OTU. Results indicated that Methanobacterium formicicum was the dominant species in all reactors; this indicated that $\mathrm{CH}_{4}$ was generated by an indirect way. Methanosarcina can mediate both hydrogenotrophic and acetoclastic methanogenesis. ${ }^{\mathbf{1 4}}$ Therefore, it was also possible that Methanosarcina could utilize $\mathrm{H}_{2}$ directly in R1. For reactor R3, the hydrogenotrophic genus Methanoculleus showed a higher relative abundance, which could be related with the utilization of $\mathrm{H}_{2} \cdot{ }^{28}$ Based on the abovementioned finding, $\mathrm{CO}$ was converted to methane mainly by indirect pathway, and $\mathrm{H}_{2}$ was converted to methane mainly by direct pathway.

\section{Conclusions}

Simulated pyrolysis gas (SPG) can be used as a carbon source for biogas production in long-term anaerobic digestion tests. Gasliquid mass transfer is the limitation for biomethanation of SPG. Gas-liquid mass transfer can be improved by mixing. The addition of $\mathrm{H}_{2}$ to anaerobic reactor could bioupgrade SPG to high quality biogas $\left(91.1 \% \mathrm{CH}_{4}\right)$. Pyrolysis combined with anaerobic digestion is an attractive way to utilize biomass and produce higher quality biogas (mainly $\mathrm{CH}_{4}$ ). Further research on the operation optimization to increase the efficiency of pyrolysis gas biomethanation should be performed. In addition, the effect of impurities on the bioupgradation conversion process should be concerned.

\section{Conflicts of interest}

There are no conflicts to declare.

\section{Acknowledgements}

This work was supported by the National Natural Science Foundation of China (No. 51508572), Beijing Municipal Science and Technology Project (No. Z161100001316010), Beijing Nova Program (No. Z171100001117058), and Science Foundation of China University of Petroleum, Beijing (No. 2462014YJRC034 and C201604). Authors also acknowledge the assistance provided by Sheng Deng, Yafei Wang, China University of Petroleum Beijing (CUPB), Beijing, P. R. China, 102249.

\section{Notes and references}

1 S. Ferreira, E. Monteiro, P. Brito and C. Vilarinho, Renewable Sustainable Energy Rev., 2017, 78, 1221-1235.

2 J. Liu, L. Yu, Z. Zhao, Y. Chen, P. Zhu, C. Wang, Y. Luo, C. Xu, A. Duan and G. Jiang, J. Catal., 2012, 285, 134-144.

3 Y. Luo, V. K. Guda, P. H. Steele and H. Wan, BioResources, 2016, 11, 4415-4431.

4 Y. Luo, V. K. Guda, P. H. Steele, B. Mitchell and F. Yu, Energy Convers. Manage., 2016, 112, 319-327.

5 B. Steubing, R. Zah, P. Waeger and C. Ludwig, Renewable Sustainable Energy Rev., 2010, 14, 2256-2265. 
6 S. Cheng, L. Wei, J. Julson, K. Muthukumarappan, P. R. Kharel and E. Boakye, Fuel Process. Technol., 2017, 162, 78-86.

7 Y. Luo, E. B. Hassan, P. Miao, Q. Xu and P. H. Steele, Fuel, 2017, 209, 634-642.

8 Y. Li, R. Zhang, Y. He, C. Zhang, X. Liu, C. Chen and G. Liu, Bioresour. Technol., 2014, 156, 342-347.

9 Y. Luo, V. Guda, R. Wijayapala and P. H. Steele, Energy Convers. Manage., 2016, 115, 159-166.

10 F. Monlau, C. Sambusiti, N. Antoniou, A. Barakat and A. Zabaniotou, Bioresour. Technol., 2015, 148, 32-38.

11 Y. Li, R. Zhang, Y. He, X. Liu, C. Chen and G. Liu, Energy Fuels, 2014, 28, 3759-3765.

12 G. Luo, W. Wang and I. Angelidaki, Environ. Sci. Technol., 2013, 47, 10685-10693.

13 S. R. Guiot, R. Cimpoia and G. Carayon, Environ. Sci. Technol., 2011, 45, 2006-2012.

14 W. Wang, L. Xie, G. Luo, Q. Zhou and I. Angelidaki, Bioresour. Technol., 2013, 146, 234-239.

15 S. Youngsukkasem, K. Chandolias and M. J. Taherzadeh, Bioresour. Technol., 2015, 178, 334-340.

16 E. Oelgeschläger and M. Rother, Arch. Microbiol., 2008, 190, 257-269.

17 X. Liu, Y. Wu, R. Shmulsky, Y. Luo, X. A. Wang, I. W. Chu and H. Wan, BioResources, 2016, 11, 5299-5311.
18 K. Alaimo, R. R. Briefel, E. A. Frongillo Jr and C. M. Olson, Am. J. Public Health, 1998, 88, 419-426.

19 Y. Li, R. Zhang, C. Chen, G. Liu, Y. He and X. Liu, Bioresour. Technol., 2013, 149, 406-412.

20 H. Nie, H. F. Jacobi, K. Strach, C. Xu, H. Zhou and J. Liebetrau, Bioresour. Technol., 2015, 178, 238-246.

21 G. Luo and I. Angelidaki, Appl. Microbiol. Biotechnol., 2013, 97, 3739-3744.

22 G. Luo and I. Angelidaki, Appl. Microbiol. Biotechnol., 2013, 97, 1373-1381.

23 S. K. Khanal, Anaerobic biotechnology for bioenergy production: principles and applications, John Wiley \& Sons, 2011.

24 M. Rother and W. W. Metcalf, Proc. Natl. Acad. Sci. U. S. A., 2004, 101, 16929-16934.

25 A. M. Henstra, J. Sipma, A. Rinzema and A. J. Stams, Curr. Opin. Biotechnol., 2007, 18, 200-206.

26 Y. Luo, J. Street, P. Steele, E. Entsminger and V. Guda, BioResources, 2016, 11, 10433-10447.

27 G. Luo, D. Karakashev, L. Xie, Q. Zhou and I. Angelidaki, Biotechnol. Bioeng., 2011, 108, 1816-1827.

28 D. Z. Sousa, M. A. Pereira, A. J. Stams, M. M. Alves and H. Smidt, Appl. Environ. Microbiol., 2007, 73, 1054-1064. 